\title{
Analysis of Working Postures on the Low Back Pain in Traditional Songket Weaving Craftsmen in Ketang Manggarai Village, East Nusa Tenggara
}

\section{Yuliana Suryati, Bonavantura Nursi Nggarang}

\author{
Faculty of Health and Agricultural Sciences, Indonesia Catholic University of Saint Paul Ruteng, \\ Manggarai, East Nusa Tenggara
}

\section{ABSTRACT}

Background:_Low back pain (LBP) is pain that is experienced in between the corners of the lower ribs to the fold of the lower buttocks, namely the lumbar-sacral area and is often accompanied by pain radiations to the legs and feet. LBP is caused by sitting for a long time in a monotonous position, causing tension on back muscles and can lead to the surrounding soft tissue damage. Traditional cloth weavers are at risk of LBP due to their activities that requiring sitting and bending positions, in a same certain position and for a long time. Analysis of appropriate working posture can be a reference to reduce the risk of LBP. This study aims to determine working posture and its effect on the incidence of LBP and the risk level of each work attitude element of the woven fabric manufacturing activity.

Subjects and Method: This was a quantitative study using a retrospective study. The subjects of this study were 40 weavers of traditional fabrics. The dependent variable was working posture. The independent variable was low back pain (LBP). LBP pain measured using the numeric rating scale (NRS) and the Quick
Exposure Check (QEC) questionnaire to determine working posture.

Results: There was a significant relationship between LBP and working posture (QEC level) $(\mathrm{OR}=0.15 ; 95 \% \mathrm{CI}=0.03$ to $0.71 ; \mathrm{p}=0.017)$, age $(\mathrm{OR}=5.64 ; 95 \% \mathrm{CI}=1.07$ to $2.96 ; \mathrm{p}=$ 0.001 ), and tenure $\mathrm{OR}=0.44 ; 95 \% \mathrm{CI}=0.16$ to $0.85 ; \mathrm{p}=0.014$ ). Age and tenure (hours) also influence the incidence of LBP.

Conclusion: Age, working experience (length of work), and working posture have a high contribution to the incidence of Low back pain. The results of this study expected to be a reference of comfortable working posture for workers and efforts to prevent and manage low back pain.

Keywords: working posture, low back pain

\section{Correspondence:}

Yuliana Suryati. Faculty of Health Science, Universitas Katolik Indonesia Santu Paulus $\mathrm{Ru}-$ teng. Jl. Ahmad Yani 1o Manggarai, East Nusa Tenggara. Email: syulty12@gmail.com. Mobile: 081328430358.

Cite this as:

Suryati Y, Nggarang BN (2020). Analysis of Working Postureson the Low Back Pain Incidence in Traditional Songket Weaving Craftsmen in Ketang Manggarai Village, East Nusa Tenggara. J Epidemiol Public Health. 05(04): 469-476. https://doi.org/10.26911/jepublichealth.2020.05.04.09.

cc) (i) (-) Journal of Epidemiology and Public Healthis licensed under a Creative Commons EY NG SA Attribution-NonCommercial-ShareAlike 4.o International License.

\section{BACKGROUND}

Low back pain (LBP) is a musculoskeletal disorder caused by physical disturbances and incorrect mobilization. Almost $80 \%$ of the population have ever experienced LBP in their life and LBP is the second complaint that often arises after a respiratory system disorder (Chen, 2018). Statistically, the lifetime prevalence of LBP is as high as $84 \%$ and around $11 \%-12 \%$ of people with LBP suffer from disabilities. Until 2016, LBP contributed $7.2 \%$ of the causes of disability (YLD) in developed and developing countries of the total YLDs (Alsufiany et al., 2020). The incidence of LBP in Indonesia is 
Suryati et al./ Working Postures on the Low Back Pain in Traditional Songket Weaving Craftsmen

$18.2 \%$ in men and $13.6 \%$ in women (Umami, 2014).

Back pain usually resolves on its own, resolves in 4-8 weeks in more than $50 \%$ of patients, but the recurrence rate is high, about $85 \%$, due to the complexity of the bone elements, muscular ligaments, nerves, and lack of specificity. One of the complex musculoskeletal problems (acute lumbosacral strain, lumbosacral ligament instability and muscle weakness, spinal stenosis, intervertebral disc problems, unequal limb length) causes most LBP events. Based on its' duration, LBP can be divided into acute LBP (1 to 3 months), and chronic back pain (CLBP) (more than 3 months) (Chen, 2018).

One of the predicting factors for LBP incidence is incorrect posture such as head bending forward, the shoulders arched forward, the abdomen protruding forward and excessive lumbar lordosis can cause muscle spasm (muscle tension) (Boughattas et al., 2017). Working posturesdescribing the joints' angle, the vertical position of the body, head, hands, feet, the shape of the spinal curve either in the relationship between these body parts or the location of their center of gravity. These factors will determine the efficiency of body working postures (Natosba and Jaji, 2016).

Working postures are determined by the shape, arrangement, size, and placement of the working tools that are used and their operating methods (types of motion, direction, and strength). Unnatural body positions and non-ergonomic ways of working for a long and continuous time can cause various health problems for workers. Working for a long time in the same position, both standing and sitting will cause discomfort (Vahdati et al., 2014). The working posture such as sitting for a long time without any adjustment can soften the abdominal muscles, developing curvature of the spine and causing disorders on respiratory and digestive organs (Adamiak and Milewska, 2015).

The study results by Harwanti et al (2014) in Banyumas Regency on 60 written batikwomen workers showed that $86.7 \%$ experienced LBP (Harwanti et al, 2016). The variables associated with LBP are exercise habits, working time, and length of working. Nastoba and Jaji (2016) showed that there is a relationship between ergonomic position and the incidence of LBP in songket weavers in Kampung BNI 46. Traditional cloth weavers are workers, who work in a sitting position for a long time and repeated every day with high accuracy, thus increase the risk of LBP. The results of other studies show that workers who sit continuously for 91-300 minutes have a risk of developing LBP 2.35 times greater when compared to workers who sit for 5-90 minutes (Harkian et al. 2014).

Therefore, the purpose of this study was to determine the working postures and their effect on the incidence of low back pain in traditional cloth weavers and to determine the risk level of each working postures as the element of the traditional woven songket fabric.

\section{SUBJECTS AND METHOD}

\section{Study design}

This study was a retrospective study. The study was carried out within a span of 1 year in Ketang Village, Manggarai Regency, East Nusa Tenggara.

\section{Population and samples}

The population in this study were all weavers who were still active in weaving activities and not in total bed rest conditions. Sampling method using total sampling with a sample size of 40 respondents. 
Suryati et al./ Working Postures on the Low Back Pain in Traditional Songket Weaving Craftsmen

\section{Study Variables}

The dependent variable of the study was working postures. The independent variable was low back pain (LBP).

\section{Operational Definition of Variables}

Working Postures was a style or attitude taken by workers when doing work. Assessment of work posture includes limbs and work postures which more are often done during weaving.

LBP was the respondent's perception of pain complaints that are felt in the lower back area, not a disease or a diagnosis for a disease but a term for pain felt in the affected anatomic area with various variations in the duration of pain.

\section{Study Instruments}

Working Postures were assessed using the Quick Exposure Check (QEC) method to determine the final score and risk level of working postures.

LBP was measured using the Numeric Rating Scale (NRS) parameter which is indicated by the respondent reports the level of pain that has been previously described by the researcher with a pain scale from 0 to 10 (no pain until severe pain).

\section{Data Analysis}

Data processing was carried out using the SPSS 23 computer program (Statistical Social Sciences 23). Univariate analysis was used to determine the distribution of frequencies and percentages of the characterristics of study subjects. Bivariate analysis was carried out between the dependent and independent variables to determine the correlation between the two variables. This bivariate analysis used the chi-square test with a significance level of $\mathrm{p}<0.05$ and an odds ratio calculation with a 95\% confidence level.

\section{Research Ethic}

This study received the approval of the Research Ethics Committee, Universitas Katolik Indonesia Santu Paulus with number10/SK-IIIa/WAREK I-02/k/o3/2020.

\section{RESULTS}

\section{Sample Characterize}

The results of the study showed that the average age of 40 respondents were $36-45$ years as much as 14 respondents (35\%) and a small proportion of respondents aged 5656 years as much as 4 respondents (10\%). Most of the respondents have elementary education, as much as 34 respondents (85\%) and 1 respondent (2.5\%) have high school education. The majority of the respondents have length of work $>10$ years, namely 28 people (70\%) and a small proportion of respondents with a working duration of 1-5 years were 3 respondents (7.5\%). The majority of the respondents having moderate LBP levels as much as 24 respondents (60\%) and 6 respondents (15\%) had severe pain levels. The results of the Quick Exposure Check Level (QEC Level) showed that as many as 17 respondents (42.5) needed further research and changes, 5 respondents (12.5\%) were in safe conditions (Table 1). The results of the Quick Exposure Check Level (QEC) score calculation showed that most of the respondents (35\%) with the exposure score for the back are at a high level, while for the shoulders (37.5\%), wrists (50\%) and neck $52 \%$ ) is at a moderate level (Table 2). 
Suryati et al./ Working Postures on the Low Back Pain in Traditional Songket Weaving Craftsmen

Tabel 1. Sampel analysis

\begin{tabular}{|c|c|c|}
\hline Variables & $\mathbf{f}$ & $\%$ \\
\hline \multicolumn{3}{|l|}{ Age } \\
\hline 25-35 years & 11 & 27.5 \\
\hline 36-45 years & 14 & 35.0 \\
\hline 46-55 years & 11 & $27 \cdot 5$ \\
\hline 56-65 years & 4 & 10.0 \\
\hline \multicolumn{3}{|l|}{ Education } \\
\hline Elementary school & 34 & 85.0 \\
\hline Junior high school & 5 & 12.5 \\
\hline Senior High school & 1 & 2.5 \\
\hline \multicolumn{3}{|l|}{ Length of work } \\
\hline 1-5 years & 3 & $7 \cdot 5$ \\
\hline$>5-10$ years & 9 & 22.5 \\
\hline$>10$ years & 28 & 70.0 \\
\hline \multicolumn{3}{|l|}{ LBP_Level } \\
\hline Light & 10 & 25.0 \\
\hline Moderate & 24 & 60.0 \\
\hline Weight & 6 & 15.0 \\
\hline \multicolumn{3}{|l|}{ QEC_Level } \\
\hline Secure & 5 & 12.5 \\
\hline Needs further research & 8 & 20.0 \\
\hline Further research is needed and changes are made & 17 & 42.5 \\
\hline Research and posture changes are carried out immediately & 10 & 25.0 \\
\hline
\end{tabular}

Tabel 2. Analysis of QEC score

\begin{tabular}{lcccccccc}
\hline \multirow{2}{*}{ LBP level } & \multicolumn{2}{c}{ Back } & \multicolumn{2}{c}{ Shoulder/Sleeve } & \multicolumn{2}{c}{ Wrist } & \multicolumn{2}{c}{ Neck } \\
\cline { 2 - 9 } & $\mathbf{n}$ & $\mathbf{\%}$ & $\mathbf{n}$ & $\mathbf{\%}$ & $\mathbf{n}$ & $\mathbf{\%}$ & $\mathbf{n}$ & $\mathbf{\%}$ \\
\hline Low & 7 & 17.5 & 11 & 27.5 & 12 & 30.0 & 3 & 7.5 \\
Moderate & 10 & 25.0 & 15 & 37.5 & 20 & 50.0 & 21 & 52.5 \\
High & 14 & 35.0 & 12 & 30.0 & 8 & 20.0 & 8 & 20.0 \\
Very High & 9 & 22.5 & 2 & 5.0 & 0 & 0 & 8 & 20.0 \\
\hline
\end{tabular}

\section{Bivariate Analysis}

Based on the results of the chi square test, there was a significant relationship between age and the LBP level $(\mathrm{p}=0.001)$. There was no significant relationship between length of work and the LBP level ( $\mathrm{p}>$ o.05) (Table 3). There is a significant relationship between the QEC level and the LBP level $(\mathrm{p}=$ 0.001) (Table 4). 
Suryati et al./ Working Postures on the Low Back Pain in Traditional Songket Weaving Craftsmen

Tabel 3. Bivariate analysis of age and time of work against LBP level

\begin{tabular}{|c|c|c|c|c|c|c|}
\hline \multirow{2}{*}{$\begin{array}{l}\text { Independent } \\
\text { Variables }\end{array}$} & \multicolumn{3}{|c|}{ LBP Level } & \multirow{2}{*}{ OR } & \multirow{2}{*}{$95 \% \mathrm{CI}$} & \multirow{2}{*}{$\mathbf{p}$} \\
\hline & Light & Moderate & Weight & & & \\
\hline \multicolumn{7}{|l|}{ Age } \\
\hline 25-35 years & 6 & 5 & o & & & 0.001 \\
\hline 36-45 years & 4 & 10 & o & 5.64 & $1.07-2.96$ & \\
\hline 46-55 years & $\mathrm{O}$ & 8 & 3 & & & \\
\hline 56-65 years & o & 1 & 3 & & & \\
\hline \multicolumn{7}{|l|}{ Tenure } \\
\hline 1-5 years & 3 & $\mathrm{O}$ & o & 0.44 & $0.16-0.85$ & 0.014 \\
\hline$>5-10$ years & 2 & 7 & O & & & \\
\hline$>10$ years & 5 & 17 & 6 & & & \\
\hline
\end{tabular}

Tabel 4. Bivariate analysis of QEC Level against LBP

\begin{tabular}{|c|c|c|c|c|c|c|}
\hline \multirow{2}{*}{ Independent Variables } & \multicolumn{3}{|c|}{ LBP Level } & \multirow{2}{*}{$\mathbf{O R}$} & \multirow{2}{*}{ 95\%CI } & \multirow{2}{*}{$\mathbf{p}$} \\
\hline & Light & Moderate & Weight & & & \\
\hline \multicolumn{7}{|l|}{ QEC Level } \\
\hline Secure & 6 & 5 & o & 0.15 & $0.03-0.71$ & \\
\hline Needs further research & 4 & 10 & $\mathrm{O}$ & & & 0.170 \\
\hline $\begin{array}{l}\text { Further research and change } \\
\text { are needed }\end{array}$ & $\mathrm{O}$ & 8 & 3 & & & \\
\hline $\begin{array}{l}\text { Research and changes are } \\
\text { carried out as soon as possible }\end{array}$ & O & 1 & 3 & & & \\
\hline
\end{tabular}

\section{DISCUSSION}

\section{The Effect of Age on Lower Back} Pain

This study shows a significant relationship between ages, low back pain where weavers aged 46-55 years had moderate and severe pain on average, while weavers aged 36-45 had moderate pain. Several important risk factors are associated with the incidence of LBP, namely individual factors, including age, length of work, educational background (Lionel, 2014). Musculoskeletal disorders occur with increasing age. Musculoskeletal disorders begin at the age of 30 years in the form of tissue damage, replacement of tissue into scar tissue (fibrosis), and reduction of fluid, and will continue to increase with age reaching a peak at around 50-55 years of age. This situation reducing the stability of the bones and muscles and decreasing the elasticity of the intervertebral discs. The incidence and prevalence of severe and chronic LBP increase with age. This happened because, in middle age, muscle strength and endurance begin to decline, so the risk of muscle complaints increases (Wong et al., 2017). This is in line with the previous study states that as you get older, the risk of suffering from musculoskeletal pain also increases (Wong et al., 2018).

\section{The Effect of Working Period on Low Back Pain}

The results of this study show that weavers with a length of work $>10$ years had moderate and severe pain levels on average and weavers with a working duration of 5-10 years had mild and moderate pain levels on average, although statistically there was no significant relationship between the length of work with low back pain. The working period is the period or length of work activities usually in years. The study result 
from Harwanti et al. (2018) shows that there is a significant relationship between tenure and LBP. People with long working tenure are more at risk of suffering from LBP (Harwanti et al., 2018). The increased risk of LBP occurs in someone who works for a period of $>5$ years compared to workers who work for a period of $<5$ years. This is because the longer the working period, the higher the exposure to risk factors which results in the disc cavity narrowing and spinal degeneration. Physical stress for long results in reduced muscle performance where there is less movement. The pressures will accumulate daily for a long time, causing health problems. The long working period results in fatigue of the physical endurance of the muscles and bones, causing low back pain.

\section{The Relationship between Working Posture and Low Back Pain}

The results of this study indicate that there is a significant relationship between exposure level and LBP, of which $42.5 \%$ of weavers need further studies and changes and $25 \%$ of weavers have to change posture immediately. From the calculation of the exposure score (QEC score), it can be seen that the score of pain in the back area is at a high level and for the shoulders, wrists and neck are at a moderate level meaning that the risk of injury is high. Several types of work (workload, work position, reps and duration, Body Mass Index (BMI), work stress, lifting load), physical environment (vibration and noise) require certain work postures that force workers to always be in a non-physiological working posture for a long time, resulting in workers feeling quickly tired, developing pain complaints led to product defects and even body defects. The load weight that is lifted, the frequency of lifting, and the method or technique of lifting weights can often affect the health of workers in the form of working accidents or the onset of back pain or injury (Almoallim et al., 2014). The Occupational Safety and Health Administration (OSHA) states that sewing and weaving are risky jobs thancreating ergonomic problems. In a competitive working environment, workers are required to work more actively to fulfill their daily needs (Natosba., 2016).

A study conducted by Natosba and Jaji (2016) showed that there is a significant difference between back pain before and after given ergonomic position, namely a chair back in weaving songket. The use of ergonomic positions affects reducing low back pain, besides the workers become more productive in weaving (Natosba and Jaji, 2016).

The working postures consist of a sitting position and a standing position, a sitting position where the legs were not burdened with body weight and it is a stable posture for work. Meanwhile, the standing position is where the spine is vertical and the body weight is balanced on two legs (Vahdati et al., 2014). Working postures aredetermined by age, the ability to move joints, muscle and bone strength, and vision. Besides, the type of works also affects working posture, such as hand strength, resting time, the height of the working platform, surface conditions or fields of work, lighting, etc. Improper work posture for a long time causes are duction of blood flow to the muscles. This causes postural strain and leads to muscle fatigue and further reducing worker's ability and strength, creating pain complaints, particularly in the back, buttocks, and radiating to the legs. The pain is caused by a constant burden on the muscles for a long time (Muhith, 2018).

Low Back Pain decreases the level of work productivity, reduces working performance, quality of work, work concentra- 
Suryati et al./ Working Postures on the Low Back Pain in Traditional Songket Weaving Craftsmen

tion, and indirectly increases the risk of accidents. Inappropriate working postures are considered able to increase the risk of musculoskeletal disorders (MSD), especially low back pain, therefore workers have to work ergonomically because someone doing their activities using uncontrolled muscle work will develop muscle disorders. Muscle tension and spasms are one of the most common reasons for LBP. In other cases, LBP can be associated with different pain generators, with specific characteristics, such as radicular, facet joint, sacroiliac, and disco-genic pain, as well as spinal stenosis (Almoallim et al., 2014); (Allegri et al., 2016). In this study, it can be concluded that age, years of service, and working postures have a high contribution to the incidence of low back pain. The results of the study are considered as reference material for the proper working postures or attitude so that it can improve more comfortable working postures for workers, be it working posture standing, sitting, lifting, or transporting. The results of this study are expected to be a reference for the related parties in the efforts to prevent and manage lower back pain incidence.

\section{AUTHOR CONTRIBUTION}

Yuliana Suryati formulated the concepts, designing research method-logies, collected the data, analyzed the data results and interpreted them. Bonavantura Nursi Nggarang contributed in collected the data, analyzed the data results and interpreted them.

\section{CONFLICT OF INTEREST}

There is no conflict of interest in this study.

\section{FUNDING AND SPONSORSHIP}

This research was funded by Hibah Dikti 2020.

\section{ACKNOWLEDGEMENT}

The researcher would like to thank all the respondents, the village administration for providing the researchers with the opportunity to conduct this study.

\section{REFERENCE}

Adamiak MC, Milewska MM, Bukowska IS (2015). Low back pain - axioms and controversies. Ulutas Med J. 1(4): 9499.

Allegri M, Montella S, Salici F, Valente A, Marchesini M, Compagnone C, Baciarello $\mathrm{M}$, et al. (2016). Mechanisms of low back pain: A guide for diagnosis and therapy. F10ooRes. 5: F1000 Faculty Rev-1530. https://dx.doi.org/10.12688\%2Ff10ooresearch.8105.1.

Almoallim H, Alwafi S, Albazli K, Alotaibi M, Bazuhair T (2014). A simple approach of low back pain. Int $\mathrm{J}$ Clin Med. 5(17): 1087-1098. http://dx.doi.org/10.4236/ijcm.2014.517139.

Alsufiany MB, Lohman EB, Daher NS, Gang GR, Shallan AI, Jaber HM (2020). Non-specific chronic low back pain and physical activity: A comparison of postural control and hip muscle isometric strength: A cross-sectional study. Medicine (Baltimore). 99(5): e18544. https://doi.org/10.1097/md.ooooooooooo18544.

Boughattas W, Maalel OE, Maoua M, Bougmiza I, Kalboussi H, Brahem A, Chatti $S$, et al. (2017). Low back pain among nurses: Prevalence, and ccupational risk factors. 5(1): 26-37. https://doi.org/10.4236/odem.2017.51003.

Harkian Y, Dewi DRL, Fitrianingrum L (2014). Hubungan antara lama dan sikap duduk terhadap kejadian nyeri punggung bawah di poliklinik saraf RSUD Dokter Soedarso'. pp. 1-13.

Harwanti S, Aji B, Ulfah N (2016). Pengaruh posisi kerja ergonomi terhadap 
Suryati et al./ Working Postures on the Low Back Pain in Traditional Songket Weaving Craftsmen

low back pain (LBP) pada pekerja batik di Kauman Sokaraja. 8(1): 4955. http://jos.unsoed.ac.id/index.ph$\mathrm{p} /$ kesmasindo/article/view/141/130.

Harwanti S, Ulfah N, Nurcahyo PJ (2018). Faktor-faktor yang berpengaruh terhadap low back pain (LBP) pada pekerja di home industri batik Sokaraja Kabupaten Banyumas. J Kesmas Indones. 10(2): 109-23.

Jiang X, Chen D (2018). Magnetic resonance imaging analysis of work-related chronic low back pain: comparisons of different lumbar disc patterns. J Pain Res. 11: 2687-2698. https://dx.doi.org/10.2147\%2FJPR.S1 62988.

Lionel KA (2014). Risk factors for chronic low back pain in adults. A case control study done in Sri Lanka. J Pain Relief 3(5): 162. https://dx.doi.org/10.4172/2167-0846.1000162.

Muhith A (2018). Work position and low back pain in elderly farmer. UNEJ eProceeding. 24-28. https://jurnal.unej.ac.id/index.php/prosiding/article/v iew/7183.

Natosba J, Jaji (2016). Pengaruh posisi ergonomis terhadap kejadian low back pain pada penenun songket di kampung BNI 46. Jurnal Keperawatan Sriwijaya. 3(2355): 8-16. https://- media.neliti.com/media/publications /181761-ID-pengaruh-posisi-ergonomis-terhadap-kejad.pdf.

Umami D (2014). Hubungan antara karakteristik responden dan sikap kerja duduk dengan keluhan nyeri punggung bawah (low back pain) pada pekerja batik tulis. Pustaka Kesehatan. 2(1): 72-78.

Vahdati SS, Khiavi RS, Ghafouri RR, Adimi I (2014). Evaluation of prevalence of low back pain among residents of Tabriz University of medical sciences in relation with their position in work. Turk J Emerg Med. 14(3): 125-9. https://doi.org/10.5505/1304.7361.2014.79106.

Wong AYL, Forss KS, Jakobsson J, Schoeb V, Kumlien C, Borglin G (2018). Older adult's experience of chronic low back pain and its implications on their daily life: Study protocol of a systematic review of qualitative research. Syst Rev. 7: 81. https://doi.org/10.1186/s13643-018-0742-5.

Wong AYL, Karppinen J, Samartzis D (2017). Low back pain in older adults: risk factors, management options and future directions. Scoliosis Spinal Disord. 12: 14. https://doi.org/10.1186/s13013-017-0121-3. 